\title{
A COAXIAL CIRCLE CIRCUIT: COMPARISON WITH CONVENTIONAL CIRCLE AND BAIN CIRCUIT
}

\author{
JOHN SHANDRO
}

\begin{abstract}
A coaxial system to be used for gas delivery to patients in a closed or low fresh gas flow anaesthetic system is described. The resistance to gas flow, humidity of inspired gases, and static compliance of the circuit are provided and compared with the circle tubing customarily employed or the coaxial Mapleson D ("Bain") circuit. The resistance to gas flow is highest in the coaxial circle and "Bain" circuits; the resistance of the conventional circle is approximatcly 40 per cent less. Static compliance of this coaxial circle is 50 per cent greater than the conventional circle. During artificial ventilation humidity of inspired gases is maintained at levels recommended in the literature for all circuits, but during spontaneous breathing only the conventional rubber circle maintains appropriate levels. Advantages of this coaxial circle over the conventional circle include light weight and small size. Advantages of this coaxial circle over the "Bain" circuit include lower fresh gas flows and improved humidity during spontaneous breathing. These advantages make this coaxial circle useful for routine use.
\end{abstract}

KEY WORDS: EQUIPMENT, coaxial circle circuit, resistance, compliance, humidification.

THERE IS a need for a flexible, light, compact anaesthetic circuit that will permit the use of low fresh gas flow rates. I have developed a coaxial circle circuit which meets these criteria.

The circuit consists of a plastic block in which channels have been drilled to fit onto a British Oxygen Company (B.O.C.) Mk 4 circle absorber (Figures 1,2). There is provision for an oxygen monitoring electrode in the channel for inspired gas. The channels lead into two concentric pipes, the inspired gases passing into the external one, and the expired gases returning through the internal pipe. At one side of this plastic block the two concentric pipes connect to two concentric flexible plastic tubes. The external tube is of reinforced wire coil construction, the internal one of corrugated plastic. These tubes can be disconnected for sterilization. The circuit ends in a fitting which connects to face mask or tracheal tube. Thus gases can reach the patient and return through the expiratory side of the circle.

The function of this coaxial circle was studied along with the function of the conventional circle and the "Bain" circuit both in the laboratory and during clinical anaesthesia.

John Shandro, M.D., Resident in Anaesthesia, University of Alberta Hospital, Edmonton, Alberta.

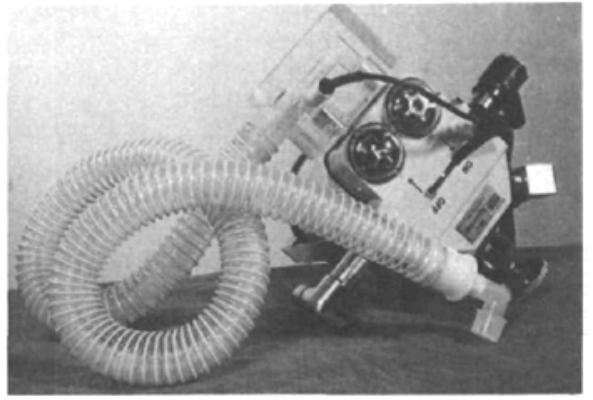

Figure 1 Coaxial circle installed on absorber.

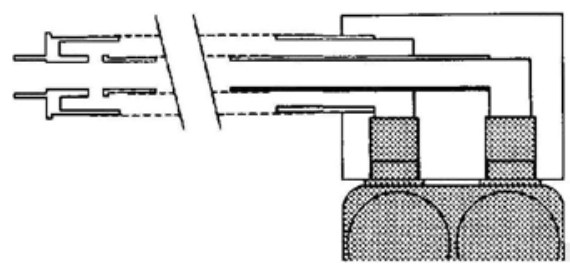

FIguRE 2 Coaxial circle cut-away drawing.

\section{LABORATORY STUDIES}

\section{Resistance to gas flow}

Resistances of the conventional circle, coaxial circle, and "Bain" circuit were measured. All 
circuits were fully assembled, pressure relief valves were closed and fresh gas inlets were plugged. In the circle the carbon dioxide absorber was on. A variable flow generator* was employed to blow air at room temperature through either the inspiratory limb - entering at the breathing bag and exiting at the patient connection, or through the expiratory limb - entering at the patient connection and exiting at the breathing bag. Flow rates of 10 to 18 litres per minute were used, and measurements were verified by repeating the tests on two occasions. The system was allowed to stabilize at each fow rate for fifteen seconds before the pressure was recorded. The amount of pressure required to achieve a given flow rate was measured at the point at which air entered the circuit by means of a diaphragm type strain gauge $\dagger$ calibrated to a water manometer standard. Results are shown graphically in Figure 3 .

The resistance increases in all circuits in a non-linear fashion because of turbulence. The coaxial circle and the "Bain" circuit had the highest resistance; the resistance of the conventional circle was approximately 40 per cent less.

\section{Static Compliance}

The distensibility of the three circuits was measured. All circuits were fully assembled, with pressure limiting valves closed and fresh gas inlets and breathing bag inlets plugged. A $300 \mathrm{ml}$ syringe was used to inject known volumes of air at room temperature into each circuit through the patient end. The resulting increase in pressure up to $5.89 \mathrm{kPa}\left(60 \mathrm{~cm} \mathrm{H}_{2} \mathrm{O}\right)$ was measured by means of a Bourdon type pressure gauge calibrated to a water manometer standard. The results are shown in Figure 4.

The prototype model of this coaxial circle has a higher compliance than the "Bain" circuit or conventional circle and thus requires increased tidal volumes during artificial ventilation to compensate for expansion of the circuit.

\section{Operating Room Studies}

\section{Moisture Content of Inspired Gases}

A device was constructed to permit only inspired gases to flow through a chamber for measurement of temperature and relative humidity. The measuring chamber was positioned at

*Godart Flow Generator, N. V. Godart Co., Holland.

†Validyne MP-45, Validyne Engineering Corp. Northridge, California.

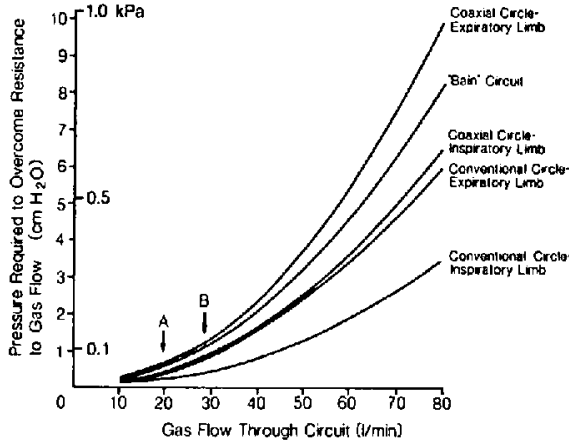

Figure 3 Pressure required to overcome resistance to gas flow is plotted against gas flow. " $\mathrm{A}$ " is the peak inspiratory flow rate of a spontaneously breathing anaesthetized patient: " $B$ " is the peak inspiratory flow rate of a conscious subject during normal tidal breathing.'

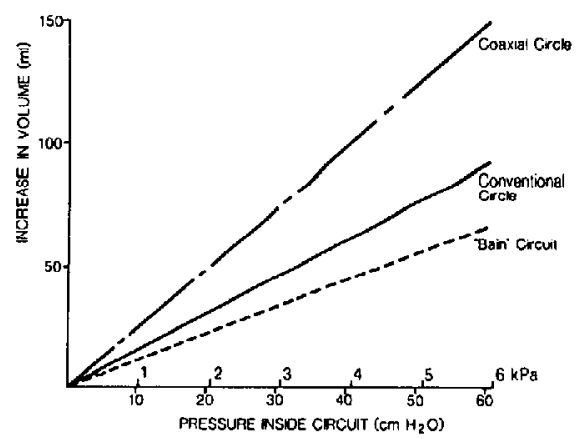

FIGURE 4 Static compliance of the three circuits. Airway pressure is plotted against increase in volume.

the machine end of the tracheal tube in all circuits. Temperature was measured by an electronic thermometer* calibrated to $\pm 0.5^{\circ} \mathrm{C}$. Humidity was measured by a crystallite fibre strain gauget calibrated with saturated salt solutions. The accuracy was found to be \pm 3 per cent relative humidity. Accuracy of measurement was unaffected by halothane or enflurane.

The circuits tested were the "Bain" circuit (Penlon) and the British Oxygen Mk 4 circle absorber with either conventional rubber tubing or our coaxial tubing.

There were a total of 21 patients of all ages in the study; none had active pulmonary or cardiovascular disease; temperature, electrolytes and fluid volumes were all normal. Patients 10 to

*Yellow Springs Instruments, Yellow Springs, Ohio.

†Model RH 515 A, Hy-Cal Engineering, Santa Fc Springs, California. 
30 kilograms weight breathed spontaneously through the "Bain" circuit; patients over 30 kilograms breathed spontaneously through either of the circle circuits. Patients who were artificially ventilated weighed 10 to 100 kilograms. Humidity measurements were made in the circle circuit at fresh gas flows of 100,50 and $25 \mathrm{ml} \cdot \mathrm{kg}^{-1} / \mathrm{min}$, first with the coaxial circle, then with the conventional rubber tubing. $\mathrm{Hu}$ midity measurements were made in the "Bain" circuit during artificial ventilation at fresh gas flows of 100 and $70 \mathrm{ml} \cdot \mathrm{kg}^{-1} / \mathrm{min}$, and during spontaneous breathing at fresh gas flows of 2.5 $X$ minute volume.

A total of 31 determinations of relative humidity and temperature were carried out. The moisture content of the inspired gases was calculated from the relative humidity and temperature information, then converted to $\mathrm{mg} \mathrm{H}_{2} \mathrm{O}$ per litre of gas. The results are presented graphically in Figure 5.

Anaesthetic gases (oxygen 30 per cent: nitrous oxide 70 per cent) supplied from the outlet on the anaesthetic machine were found to have a relative humidity of seven per cent at a temperature of $20^{\circ} \mathrm{C}$. (moisture content of $1.2 \mathrm{mg} \mathrm{H} \mathrm{H}_{2} \mathrm{O}$ per litre of gas). The circle circuit with conventional rubber tubing provided moisture content in the range of $20 \mathrm{mg} \mathrm{H}_{2} \mathrm{O}$ per litre regardless of the type of ventilation or fresh gas flows. The coaxial circle showed an improvement in moisture content as fresh gas flows were decreased during artificial ventilation, with gas flows of $25 \mathrm{ml} \cdot \mathrm{kg}^{-1} / \mathrm{min}$ providing moisture content in the same range as the conventional tubing. During spontaneous breathing the coaxial circle provided a significantly lower $(\mathrm{p}<.01)$ moisture content with little improvement with decreasing fresh gas flow.

During artificial ventilation the "Bain" circuit

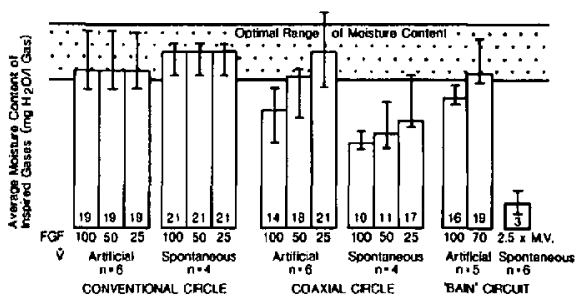

FIGURE 5 Moisture content of inspired gases produced by the circle circuit with conventional rubber tubing, coaxial tubing and the "Bain" circuit "FGF" is fresh gas flow in $\mathrm{ml} \cdot \mathrm{kg}^{-1} / \mathrm{min}$. The bars give the average humidity, the extensions indicate range. provided an average moisture content of $16 \mathrm{mg}$ $\mathrm{H}_{2} \mathrm{O}$ per litre at $100 \mathrm{ml} \cdot \mathrm{kg}^{-1} / \mathrm{min}$ fresh gas flow, which improved to $19 \mathrm{mg} \mathrm{H}_{2} \mathrm{O}$ per litre when the fresh gas flow was decreased to $70 \mathrm{ml} \cdot \mathrm{kg}^{-1} / \mathrm{min}$. During spontaneous breathing with fresh gas flow at $2.5 \times$ minute volume, the "Bain" circuit provided extremely dry inspired gases with an average moisture content of $3 \mathrm{mg} \mathrm{H}_{2} \mathrm{O}$ per litre.

\section{Discussion}

Resistance to gas flow, static compliance and humidity of inspired gases are all of importance in the function of anaesthetic circuits.

Resistance to gas flow should be minimal. In designing the coaxial circle, the breathing tube diameter, boundary layer turbulence, and turbulence from changes in direction of gas flow were carefully considered, as all of these factors affect resistance. An internal tube of internal diameter $15 \mathrm{~mm}$ and external diameter $18 \mathrm{~mm}$, and an external tube of internal diameter $30 \mathrm{~mm}$ were found to provide similar resistance to gas flow in both inspiratory and expiratory limbs of the circle, while keeping the external diameter of the circuit to a minimum and the gas flow resistance within acceptable limits. This resistance is similar to that of the "Bain" circuit, but somewhat higher than the conventional circle. However, at peak flow rates in the range generated by normal tidal volumes in adults ( 20 to 28 litres per minute ${ }^{1,2}$ ) the resistance of all the circuits was very low, the pressure required to overcome the resistance being less than $0.15 \mathrm{kPa}$ $\left(1.5 \mathrm{~cm} \mathrm{H} \mathrm{H}_{2} \mathrm{O}\right.$ ) in all cases.

Static compliance of anaesthetic circuits is important because during artificial ventilation tidal volumes must be increased to compensate for the volume loss due to distension of the circuit. Our coaxial circle has a higher compliance than the "Bain" circuit or conventional circle made of heavy corrugated rubber tubing. However, in subsequent models the rigidity of the external tubing can be increased without adversely affecting the flexibility.

Adequate humidity in the inspired gases preserves normal epithelial cell morphology, ciliary motility, mucous transport, and normal pulmonary mechanics. It is also preserves normal surfactant activity and helps keep secretions liquified, as well as diminishing heat loss. A great deal of attention has already been paid to this subject. Chalon ${ }^{3}$ and Dolorico ${ }^{4}$ have studied exfoliative cytology of the respiratory tract in man and have found that with humidity of the 
inspired gas below 60 per cent at $22^{\circ}-26^{\circ} \mathrm{C}$ the morphology of the tracheobronchial cells was significantly changed over a three hour period. Noguchi, ${ }^{5}$ and Tsuda ${ }^{6}$ studied tracheobronchial epithelial morphology, surfactant activity and pulmonary mechanics in dogs. They found that a relative humidity of 100 per cent at $20^{\circ}-30^{\circ} \mathrm{C}$ in the trachea best preserved these parameters. Déry and his co-workers ${ }^{7}$ have investigated heat and moisture exchange in patients under endotracheal anaesthesia and have shown that the water which condenses in the tracheal tube and connector during expiration is revaporized during inspiration, adding approximately 6 to $8 \mathrm{mg} \mathrm{H} \mathrm{H}_{2} \mathrm{O}$ moisture content to a litre of inspired gas. These data are by no means the final word on this subject but they do suggest an optimal range of humidity of inspired gases at the machine end of the tracheal tube of about 18 to $24 \mathrm{mg} \mathrm{H}_{2} \mathrm{O}$ per litre of inspired gas. The circle absorber with conventional rubber tubing achieves this humidity range with no special effort. The coaxial circle will provide adequate humidity during artificial ventilation at fresh gas flows below $50 \mathrm{ml} \cdot \mathrm{kg}^{-1} / \mathrm{min}$, but during spontaneous breathing the inspired gas humidity is less satisfactory. Reasons for the discrepancy between the two circuits are difficult to determine. Possibly the rubber tubing, being more porous than the plastic coaxial tubing, retains moisture after sterilization and washing or there might be differences in condensation within the circuits. Similar comments apply to the "Bain" circuit which, under most circumstances, requires supplementary humidification if moisture content of inspired gas is to be maintained at an optimal level.

During general use in the operating room our coaxial circle was more convenient to use than the conventional heavy corrugated tubes. No equipment failure has occurred with this prototype model, but one possible malfunction is disconnection or breakage of the internal tube, which, like the "Bain" circuit, would result in increased mechanical deadspace. Modifications in future models and appropriate preanaesthetic testing should render this complication even less likely.
This coaxial circle is unavailable commercially. It is currently being redesigned to be used interchangeably with different models of carbon dioxide absorbers.

\section{Conclusions}

The coaxial circle system is light, flexible, and of small diameter. It has these advantages over the conventional circle in common with the "Bain" circuit. The fact that it is suitable for closed circuit and low fresh gas flow anaesthetic techniques would indicate that it merits further development for routine use in the practice of anaesthesia.

\section{ACKNOWLEDGEMENTS}

I would like to thank Keith Bowker and Stewart Jack for their technical assistance, Dr. R. Jones and Dr. J. Armengol for their help with laboratory studies, and Isao Yamamoto for constructing the circujt components.

\section{BIBLIOGRAPHY}

1. CAIN, C.C. \& OTIS, A.B. Some physiological effects resulting from added resistance to respiration. J. Aviation Medicine 20: 149 (1949).

2. NunN, J.F. \& EZI-AsHI, T.I. The accuracy of the respirometer and ventigrator. Brit. Jour. Anaes. 34: 422 (1962).

3. Chalon, J., Leow, A.Y.L. \& Malebranche, J. Effects of dry anesthetic gases on the tracheobronchial epithelium. Ancsthesiology 37: 338 (1972).

4. Dolorico, V.N., Chalon, J., WeEks, D.B. \& ORKIN, L.R. A safe nonrebreathing system: Humidity, sterility, cost. Anes. Analg. 53: 75 (1974).

5. NoGUCHI, H., TaKUMI, Y. \& AOCHI, A. A study of humidification in tracheostomized dogs. Brit. Jour. Anaes. 45: 844 (1973).

6. TSUda, T., NOGUChI, H., TAKUmI, Y.\& AOCHI, A. Optimum humidification of air administered to a tracheostomy in dogs. Brit. Jour. Anaes. 49: 965 (1977)

7. Déry, R., Pellitier, J., Jacques, A., Clavet, M. \& HOUDE, J.J. Humidity in Anaesthesiology: heat and moisture patterns in the respiratory tract during anaesthesia with the semi-closed system. Can. Anaesth. Soc. J. 14:287 (1967).

\section{RÉsumé}

On décrit un système coaxial destiné à l'administration de gaz cn circuit fermé ou à bas débit de gaz frais. La résistance à l'écoulement des gaz, l'humidité des gaz inspirés et la compliance statique du circuit ont été déterminées et sont comparées avec les tuyaux 
ordinairement utilisés ou le circuit coaxial de type Mapleson D ("Bain"). La résistance à l'écoulement des gaz est la plus grande dans le circuit coaxial étudié et le circuit Bain; la résistance du circuit circulaire conventionnel est de 40 pour cent moindre. La compliance statique de ce circuit coaxial est de 50 pour cent plus élevée qu'avec le circuit conventionnel. Pendant l'anesthésie, l'humidité des gaz inspiratoires est maintenue au niveau recommandé dans la littérature par tous les circuits en respiration contrôlée; en respiration spontanée, seul le circuit circulaire conventionnel en caoutchouc est adéquat. Les avantages du circuit coaxial étudié comprennent son faible poids et son volume réduit; ses avantages sur le circuit Bain consistent en des besoins moindres en gaz frais et une amélioration de l'humidification en respiration spontanée. Ces avantages en font un circuit utile pour usage courant. 